\section{Scientific journal}

PHYSICAL AND MATHEMATICAL EDUCATION

Has been issued since 2013.

Науковий журнал

ФІЗИКО-МАТЕМАТИЧНА ОСВІТА

Видається з 2013.
ISSN 2413-158X (online)

ISSN 2413-1571 (print)

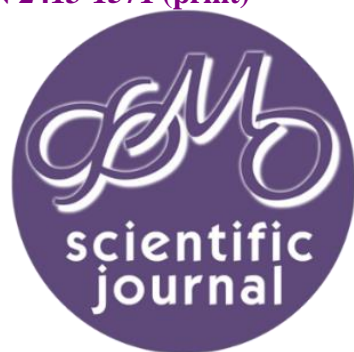

Трінтіна Н.А., Котелевець С.Є. Інформаційні технології в юридичній діяльності. Фізико-математична освіта. 2021. Випуск 1(27). С. 89-93.

Trintina N., Kotelevets S. Information technologies in legal activity. Physical and Mathematical Education. 2021. Issue 1(27). P. 89-93.

DOI 10.31110/2413-1571-2021-027-1-014

Н.А. Трінтіна

Державний університет телекомунікацій, Україна trintina2015gmail.com.

С.Є. Котелевець

Державний університет телекомунікацій, Навчально-науковий інститут Інформаційних технологій Державне підприємство "Інформаційні судові системи", Україно kotelewetz.sergei@gmail.com

\title{
ІНФОРМАЦІЙНІ ТЕХНОЛОГІї В ЮРИДИЧНІЙ ДІЯЛЬНОСТІ
}

АНОТАЦІЯ

Формулювання проблеми. У статті розглянуто актуальні напрямки використання інформаційних технології в юридичній діяльності. Усучасному світі одним з найважливіших завдань юридичної діяльності є своєчасне і повноцінне забезпечення юристів достовірною та актуальною законодавчою інформацією, а також відомостями, що включають зміни та доповнення, які вносяться до нормативно-правових документів, також актуальним є використання інформаційних технологій в процесі експертиз та прийняття важливих рішень правового характеру.

Матеріали і методи. Матеріалами статті стали наукові праці, в яких розглядаються проблеми юридичної інформатики, відомості, які стосуються окремих напрямків використання інформаційних технології в юридичній діяльності. Метод: аналіз інформаційних систем, узагальнення отриманих фоктів, класифікація інформаційних технологій, що засовуються в юридичній діяльності.

Результати. Визначено й узагальнено напрямки використання інформаційних технологій в юридичній діяльності: інформатизація правоохоронної діяльності, інформатизація правотворчості, приведення законодавства у відповідність із знову прийнятими нормативними актами, вдосконалення системи законодавства для відсутності суперечливості нормативних актів, вдосконалення процесу правотворчості, інформатизація правозастосовчої діяльності. Усі правові інформаційні ресурси, представлені в мережі Інтернет доцільно класифікувати на такі: державна влада, правові змІ в мережі Інтернет, сайти по праву, віртуальні клуби і правові форуми, правозахисні організації та юридичні фірми, WWWсторінки відомих юристів, закордонні правові ресурси..

Висновки. Подальша інтеграція інформаційних технологій в галузі правової діяльності дозволить значно скоротити час, що витрачається на прийняття рішення в межах конкретної правової ситуації, поліпшити якість і виробити правильне рімення.

КлЮчовІ словА: інформаційні технології, юридична діяльність, напрямки, пошук, експертиза, аналіз, правосуддя.

\section{ВСТУП}

Постановка проблеми. У сучасному світі одним з найважливіших завдань юридичної діяльності $€$ своєчасне повноцінне забезпечення юристів достовірною та актуальною законодавчою інформацією, а також відомостями, що включають зміни та доповнення, які вносяться до нормативно-правових документів, також актуальним $є$ використання інформаційних технологій в процесі експертиз та прийняття важливих рішень правового характеру.

При цьому на початку XXI століття фахівець юридичної галузі у своїй професійній діяльності звертається до широкого кола інформації різного типу - наукової, соціальної, юридичної, економічної чи іншого типу. При цьому, як свідчить практика юридичної діяльності, персонал правоохоронних структур, судових органів і юридичних фірм більшу частину свого часу витрачає на роботу з інформацією та на їі обробку.

У зв'язку з цим актуальним $€$ дослідження питань, пов'язаних з використанням інформаційних технологій в юридичній діяльності в зв'язку з широким колом повноважень, які дані технології відкривають перед практикуючими юристами.

(C) Н.А. Трінтіна, С.Є. Котелевець, 2021. 
Аналіз актуальних досліджень. До питань, що стосуються можливостей використання інформаційних технологій в юридичній діяльності, в останні роки зверталися О.О. Денисова, Б.А. Заплотинський, Н.В. Кушакова-Костицька, В. Дурдинець, Є. Мойсеєв, М. Швець, В.Г. Іванов, С.М. Іванов, В.В. Карасюк, В. Фрончко та ін.

Українські вчені зазначають, що в наш час йдеться про формування «цифрової» юриспруденції, яка має на меті впровадження у правотворчість та правозастосування комп'ютерної техніки, спеціального програмного комп'ютерного забезпечення, математичних методів тощо. Такі впровадження необхідні для збору, зберігання і обробки правової інформації з метою найбільш ефективного отримання різних інформаційних юридичних послуг (Фрончко, 2019).

Погоджуючись із даною тезою вважаємо за необхідне продовжити дослідження в сфері використання інформаційних технологій в юридичній діяльності, що і $€$ метою цієї статті.

\section{МЕТОДИ ДОСЛІДЖЕННЯ}

Методами, які використовувалися автором цієї статті, були аналіз інформаційних систем, узагальнення отриманих фактів, класифікація інформаційних технологій, що засовуються в юридичній діяльності.

\section{РЕЗУЛЬТАТИ ДОСЛІДЖЕННЯ}

Сьогодні наявні такі напрямки використання інформаційних технологій в юридичній діяльності:

- інформатизація правоохоронної діяльності має на меті автоматизацію робочих процесів у правоохоронних органах - прокуратурі, органах внутрішніх справ, юстиції, судових органах, арбітражі тощо;

- інформатизація правотворчості передбачає швидке і якісне забезпечення інформацією про нормативні правові акти, про зарубіжне законодавство, а також забезпечення економічною, соціальною, політичною та іншою інформацією, необхідною для розгляду в діяльності законодавців і фахівців, діючих у сфері правотворчості; визначення зв'язків створюваних норм права із законодавством;

- приведення законодавства у відповідність із знову прийнятими нормативними актами;

- своєчасне скасування або заміна старих норм права; вдосконалення системи законодавства для відсутності суперечливості нормативних актів;

- вдосконалення процесу правотворчості за рахунок запровадження нових інформаційних технологій;

- інформатизація правозастосовчої діяльності спрямована на забезпечення правовою інформацією всіх учасників правових відносин, які виконують закони чи інші норми права.

У той же час сфера застосування цих технологій в юридичній практиці постійно розширюється оскільки, як зазначає В. Фрончко, сьогодні в українському правовому полі практично немає такого виду юридичної діяльності, де 6 не використовувалися комп'ютеризація, комп'ютерні технології та Інтернет. Автоматизація багатьох суспільних процесів набуває швидких обертів. Стосується це і юридичної професії. Цифрові комп'ютерні технології в юридичній сфері розвиваються за такими напрямками: автоматизація типових юридичних послуг, застосування юридичних онлайнсервісів, «діджитилізація» державних послуг та надання їх в режимі онлайн, перехід до системи електронного правосуддя, моделювання юридичних рішень на основі штучного інтелекту та ін. (Фрончко, 2019).

У той же час специфіка юридичної діяльності сприяє тому, що сучасні юристи можуть використовувати в своїй діяльності програмне забезпечення будь-якого виду: від стандартних текстових редакторів до спеціалізованих програм обробки даних, однак, найбільш затребуваними залишаються довідково-правові системи, що представляють собою сукупність, яка містить в собі масиви правової інформації та інструменти, завдяки яким користувачем системи можуть виконуватися різного роду операції пошуку необхідних документів.

Завдяки таким інструментам можна шукати фрагменти документів, займатися виведенням документів або ї фрагментів на друк, створенням власної добірки документів з урахуванням специфіки професійної діяльності тощо.

Довідкові правові системи мають основу, яка представлена систематизацією інформації правового типу в інформаційних банках. Робота з такими системами дає юристу можливість отримати доступ до останніх редакцій правових актів і документів. Як правило, база даних цих систем має ієрархічну структуру, що дає змогу легко орієнтуватися в ії змісті та швидко знаходити потрібні розділи. Документи систематизовано за типами, тематикою, офіційними публікаціями, хронологією надходження. У будь-якому розділі бази працюють універсальні пошуки: - за словом чи контекстом у тексті; за контекстом у назві; за датою (Фрончко, 2019).

Можна з упевненістю стверджувати, що впровадження довідково-правових систем стало найважливішим досягненням інформаційної епохи в контексті юридичної діяльності.

Найважливішим елементом сучасних довідкових систем, призначених для юристів, є інформаційні ресурси Інтернету. Можливості Інтернет-ресурсів для діяльності юриста $€$ невід'ємною його частиною, оскільки робота співробітника юридичної сфери безпосередньо пов'язана з роботою з інформацією. Термін «робота з інформацією» вже давно увійшов у наш світ. Для ефективної роботи юриста в Інтернеті зібрані і $є$ в загальному доступі необхідні закони, різні поправки і постанови. Результатом застосування Інтернету в юридичній практиці є різке скорочення паперових архівів, легкість і простота публікації інформації, універсальний і природний доступ до інформації за допомогою навігаторів, суттєве скорочення витрат на адміністрування додатків на робочих місцях користувачів, негайна актуалізація будь-яких змін в інформаційному сховищі організації, зміщення акцентів від створення інформації до її ефективного споживання.

Інтернет для працівників юридичної сфери має особливе значення, оскільки там знаходиться багато правової та пов'язаної з правом інформації: нормативна правова інформація; судова практика; міжнародні аспекти правової системи; правова література; аналітична правова інформація; матеріал про факти правової дійсності; новини, матеріали статистики; контр-правова інформація (способи порушення закону).

Усі правові інформаційні ресурси, представлені в мережі Інтернет, на нашу думку, можна класифікувати таким чином: 
1. Державна влада - тобто сайти належать органам державної влади України: сайт президента України, сайти Кабінету Міністрів, Верховної Ради, сайти міністерств України, сайти судів і правоохоронних органів. Тут зібрані всі офіційні дані про структури і їх діяльність.

2. Правові ЗМІ в мережі Інтернет широко представлені. Частина з них є інтернет-версією офіційних паперових видань, інша частина з'являється і існує незалежно від них і виключно тільки в електронному вигляді.

3. Сайти по праву - створюються професійними юристами і містять матеріали з якихось правових питань, суперечок і проблем.

4. Віртуальні клуби і правові форуми - створені і ведуться групами професіоналів у сфері юриспруденції. Тут ведуться обговорення виникаючих питань із застосуванням законодавства і рішенням конкретних ситуацій.

5. Правозахисні організації та юридичні фірми - представлені як сайти, створені громадськими правозахисними структурами і організаціями, так і сайти великих і відомих юридичних фірм. Тут представлені матеріали, пов'язані $з$ різними правовими питаннями.

6. WWW-сторінки відомих юристів - представлені www-сторінки відомих вітчизняних юристів, де є дані з біографії і матеріали про їхню професійну діяльність.

7. Зарубіжні правові ресурси - наведені приклади зарубіжних (англомовних) баз даних різного типу.

Таким чином, останнім часом Інтернет ресурси стали невід'ємною частиною робочого процесу будь-якого юриста.

Також слід звернути увагу, що сучасні засоби інформатизації дозволяють юристам фіксувати необхідні дані і добувати докази. Сюди можна віднести техніку, що дозволяє робити фотографії, а також вести відеозйомку або аудіозапис. Із сучасних розробок слід виділити систему захисту свідків, яка представляє собою комплекс пристроїв, що включає в себе камеру, мікрофон, систему зміни голосу і т. ін.

Ще одним засобом, що полегшує роботу юриста, є відеоконференцзв'язок, що дає можливість проводити розгляд справ без очної присутності учасників процесу. Як докази при розгляді справ в суді нерідко використовуються дані авторегістраторів і відеокамер цілодобового спостереження.

Порівняно новим напрямом застосування інформаційних технологій у юридичній діяльності $є$ експертні системи системи штучного інтелекту, програми, що здатні накопичувати знання і моделювати процес експертизи. Поява експертних систем ознаменувала перехід від суто теоретичної сфери штучного інтелекту до прикладної. Експертні системи можуть бути корисними лише тоді, коли добре відомі способи пошуку рішення, а експерт може точно описати логіку розв'язання задачі.

\section{ОБГОВОРЕННЯ}

Найперспективнішими напрямами щодо створення цих систем ми вважаємо:

- інтеграцію експертних систем з традиційними пакетами (табличними редакторами, системами управління базами даних) з метою розв'язування завдань у формі, до якої звикли користувачі юридичної інформації;

- створення експертних систем "реального» часу при управлінні неперервними процесами (наприклад, для підвищення надійності управління потоками інформації в організаціях, що входять до складу правоохоронної системи);

- розробка динамічних експертних систем (тобто систем нереального часу, які враховують суттєві зміни, що відбуваються в процесі «обмірковування») (Заплотинський, 2018).

Перспективним напрямком використання інформаційних технологій в юридичній діяльності $\epsilon$ електронне правосуддя - явище нове і складне в змістовному плані. Актуальність цього напрямку використання інформаційних технологій у юридичній практиці пов'язана з тем, що повноцінне існування демократичної держави неможливе без системи відкритого і швидкого судочинства, але загальний стан впровадження інформаційних технологій, що автоматизують роботу судів та процесуальних дій у судовій системі України, не можна вважати доцільним. Натомість підвищення ефективності судової діяльності в умовах формування інформаційного суспільства передбачає впровадження в неї інформаційних та комунікаційних технологій, які 6 дозволили забезпечити дотримання відповідних стандартів і принципів електронного судочинства (Цимбал, Омельчук,\& Калініченко, 2017).

Тому необхідно розрізняти поняття «електронне правосуддя» в широкому і вузькому сенсах. Так, в широкому сенсі під електронним правосуддям можна розуміти сукупність різних автоматизованих інформаційних систем - сервісів, що надають засоби для публікації судових актів, ведення електронної справи і доступу сторін до матеріалів електронної справи. Вищевказані засоби дозволяють вивести на зовсім інший якісний рівень взаємодію суду, учасників процесу та інших зацікавлених осіб. У той же час всі ці сервіси носять прикладний, допоміжний характер, не змінюючи способів ведення судового процесу.

У вузькому сенсі електронне правосуддя - це можливість суду та інших учасників судового процесу здійснювати передбачені нормативно-правовими актами дії, що безпосередньо впливають на початок і хід судового процесу (наприклад, такі дії, як подача в суд документів в електронній формі або участь в судовому засіданні за допомогою системи відеоконференцзв'язку).

Під електронним правосуддям слід розуміти спосіб здійснення правосуддя, при якому судочинство відбувається за допомогою встановлених процесуальним нормативно-правовим актом спеціальних інформаційно-комунікаційних технологій, застосування яких забезпечує використання, створення і зберігання всіх використовуваних в процесі документів в електронній формі, а також обмін інформацією між усіма учасниками процесу. Електронне правосуддя відображає сучасні тенденції в розвитку держави і права, є елементом електронної держави і мережевого суспільства, представляє собою особливий спосіб і форму здійснення державної функції, адекватну сучасному рівню розвитку та інформатизації суспільства.

Дане державно-правове явище характеризують такі основні ознаки:

1) використання інформаційно-комунікаційних технологій як основного засобу здійснення всіх процесуальних дій як судом, так і сторонами, а також для здійснення дій, що забезпечують процес судочинства. При цьому застосування інформаційно-комунікаційних технологій грунтується на процесуальному нормативно-правовому акті; 
2) створення системи електронного документообігу (зовнішнього і внутрішнього), що дозволяє сторонам направляти документи в суд, а судам забезпечити належне проходження поданих документів в суді і створення електронної справи. Електронна форма документа є основною, при цьому остання використовується як повноцінний еквівалент документа на паперовому носії. По суті, в електронному правосудді паперова форма документа витісняється електронною формою;

3) запровадження системи управління електронною справою, яка дає можливість управляти інформацією, що міститься в справі і надавати доступ до інформації, як широкому, так і обмеженому колу осіб (сторонам спору), якщо інформація є конфіденційною;

4) формування системи публікації всіх судових актів;

5) забезпечення фіксації подій судових засідань за допомогою аудіовідеозапису;

6) широке використання засобів відеоконференцзв'язку для отримання усних пояснень сторонами та іншими учасниками процесу, виключення необхідності безпосередньої явки сторін в зал суду, а також для забезпечення публічності процесу;

7) використання обладнання, що дозволяє досліджувати докази, надані в електронній формі, можливість дослідження доказів судом і сторонами виключно шляхом огляду електронних документів, а також відтворення аудіоабо відеозаписів з цифрових носіїв.

Реалізація електронного правосуддя сприяє здійсненню судових функцій у прозорий спосіб, маючи на увазі при цьому механізми як внутрішньодержавного, так і громадського і професійного контролю. При цьому забезпечується відкритість інформації, i, як наслідок, з'являються нові можливості для забезпечення незалежності та неупередженості суду.

Не зважаючи на всі переваги електронного судочинства, треба зазначити і певні проблемні моменти. Це насамперед досить високий ризик втрати юридично важливої інформації, відсутність «комп'ютерної грамотності» на рівні кваліфікованих користувачів у суддів і співробітників апарату судів (що становить серйозну проблему для людей особливо старшого покоління); розроблення та введення в експлуатацію (що в наших умовах ще більш складна справа) відповідного програмного забезпечення; необхідне технічне оснащення судів. Деякі дослідники відмічають проблему впровадження електронного судочинства через психологічний аспект, адже більшість наших громадян ще надає перевагу традиційному «паперовому» судочинству (Кушакова-Костицька, 2018).

Резюмуючи, можна сказати, що інформаційні технології відіграють величезну роль в сучасній юридичній діяльності. Завдяки інформаційним технологіям вдалося домогтися прискорення прийняття юридичних рішень, удосконалено процес пошуку і систематизації доказів, а юристи отримали можливість в будь-який момент знайти всі необхідні відомості щодо актуальних законів та правових актів.

Подальша інтеграція інформаційних технологій в галузі правової діяльності дозволить значно скоротити час, що витрачається на прийняття рішень в межах конкретної правової ситуації, поліпшити якість і виробити правильне рішення.

\section{ВИСНОВКИ ТА ПЕРСПЕКТИВИ ПОДАЛЬШОГО ДОСЛІДЖЕННЯ}

Інформаційні технології відіграють величезну роль в роботі юриста. Вони допомагають знайти, узагальнити актуальну правову інформацію, оперативно обмінятися даними, надати необхідні відомості в судові органи, здійснювати експертизи, удосконалювати систему правосуддя.

Завдяки інформаційним технологіям юрист може не тільки оперативно отримувати актуальні законодавчі відомості. Вони дають можливість швидко відшукати статистичні дані, без яких часом неможливо обійтися при вирішенні різних питань. Крім того, з Інтернету фахівець може отримати будь-які дані з суміжних дисциплін.

Глибока інтеграція інформаційних технологій в юридичну діяльність призводить до прискорення процесу пошуку і підготовки необхідної документації.

Подальше дослідження буде спрямовано в напрямку визначення основних елементів інформаційних систем, що використовуються в практичній діяльності юридичних установ.

\section{Список використаних джерел}

1. Денисова О. О. Інформаційні системи і технології в юридичній діяльності: навч. посіб. Київ: КНЕУ, 2013. 315 с.

2. Заплотинський Б. А. Інформачійні технології в юридичній діяльності: навч. посіб. Київ: Київ. ін-т інтел. власн. та права НУ “Одес. юрид. ак", 2018. 108 с.

3. Кушакова-Костицька Н. В. Електронне правосуддя: українські реалії та зарубіжний досвід. Юридичний часопис Начіональної академії внутрішніх справ . 2013. № 1. С. 103-109.

4. Правова інформатика: навч. посіб. / за ред.: В. Дурдинця, Є. Мойсеєва, М. Швеця. Київ: ПанТот, 2007. 524 с.

5. Правова інформація та комп'ютерні технології в юридичній діяльності: навч. посіб. / за ред.: В.Г. Іванова. Харків: Право, 2010. 240 с.

6. Фрончко В. До питання про цифрову юриспруденцію. Актуальні проблеми правознавства. 2019. Вип. 2. С. $144-148$.

7. Цимбал П.В., Омельчук Л.В., Калініченко Л.Л. Напрями вдосконалення електронного судочинства. Міжнародний юридичний вісник: актуальні проблеми сучасності (теорія та практика). 2017. Вип. 4-5. С. 150-155.

8. Электронное правосудие. Электронный документооборот: научно-практическое пособие / под ред.: С. Ю. Чучи. Москва: Проспект, 2017. 240 с.

\section{References}

1. Denysova, O. O. (2013). Informatsiini systemy i tekhnolohii v yurydychnii diialnosti [nformation systems and technologies in legal activity]. Kyiv: KNEU [in Ukraine]. 
2. Zaplotynskyi, B. A. (2018). Informatsiini tekhnolohii v yurydychnii diialnosti [Information technologies in legal activity]. Kyiv: Kyiv. in-t intel. vlasn. ta prava NU "Odes. yuryd. ak" [in Ukraine].

3. Kushakova-Kostytska, N.V. (2013). Elektronne pravosuddia: ukrainski realii ta zarubizhnyi dosvid [Electronic justice: Ukrainian realities and foreign affairs]. Yurydychnyi chasopys Natsionalnoi akademii vnutrishnikh sprav, 1, 103-109 [in Ukraine].

4. Pravova informatyka [Legal informatics] (2007) / za red.: V. Durdyntsia, Ye. Moiseieva, M. Shvetsia. Kyiv: PanTot [in Ukraine].

5. Pravova informatsiia ta kompiuterni tekhnolohii v yurydychnii diialnosti [Legal information and computer technologies in legal activity] (2010) / za red.: V.H. Ivanova. Kharkiv: Pravo [in Ukraine].

6. Fronchko, V. (2019). Do pytannia pro tsyfrovu yurysprudentsiiu [Before the nutrition about digital jurisprudence.]. Aktualni problemy pravoznavstva, 2, 144-148 [in Ukraine].

7. Tsymbal, P.V., Omelchuk, L.V., \& Kalinichenko, L.L. (2017). Napriamy vdoskonalennia elektronnoho sudochynstva [Straight to the depth of electronic craftwork] Mizhnarodnyi yurydychnyi visnyk: aktualni problemy suchasnosti (teoriia ta praktyka), 4-5, 150-155 [in Ukraine].

8. Эlektronnoe pravosudye (2017)./ pod red.: S. Yu. Chuchy. Moscow: Prospekt [in Russia].

\section{INFORMATION TECHNOLOGIES IN LEGAL ACTIVITY}

Natalia Trintina, Sergey Kotelevets

State University of Telecommunications, State Enterprise "Information Judicial Systems", Ukraine

Abstract.

Problem formulation. The article considers the current areas of use of information technology in legal activities. In today's world, one of the most important tasks of legal activity is the timely and full provision of lawyers with reliable and up-to-date legal information, as well as information that includes changes and additions to regulations, and the use of information technology in the process of examination and adoption of important legal decisions.

Materials and methods. The materials of the article are scientific works, which consider the problems of legal informatics, information relating to certain areas of use of information technology in legal activities. Method: analysis of information systems, generalization of the received facts, classification of the information technologies which are put in legal activity.

Results. The directions of using information technologies in legal activity are defined and generalized: informatization of law enforcement activity, informatization of law - making, bringing legislation in line with newly adopted normative acts, improvement of legislation system for absence of contradictory normative acts, improvement of law - making process, informatization of law - making activity. All legal information resources presented on the Internet should be classified into the following: public authorities, legal media on the Internet, legal sites, virtual clubs and legal forums, human rights organizations and law firms, WWW-pages of famous lawyers, foreign legal resources.

Conclusions. Further integration of information technology in the field of legal activity will significantly reduce the time spent on decision-making within a specific legal situation, improve quality and develop the right decision.

Key words: information technologies, legal activity, directions, search, examination, analysis, justice. 